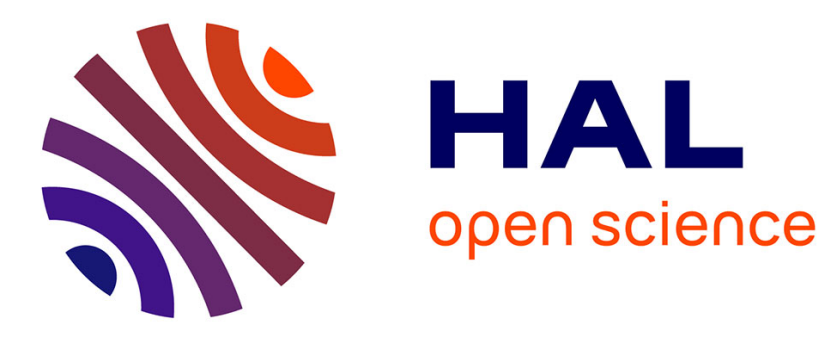

\title{
The Epistemic Communities and Evolution of Knowledge Domains: A Domain Analysis of the Journal Education for Information
}

\author{
Daniel Martínez-Ávila, Fidelia Ibekwe, Fernanda Bochi
}

\section{- To cite this version:}

Daniel Martínez-Ávila, Fidelia Ibekwe, Fernanda Bochi. The Epistemic Communities and Evolution of Knowledge Domains: A Domain Analysis of the Journal Education for Information. Proceedings of the Sixteenth International ISKO Conference, International Society for Knowledge Organization (ISKO), Jul 2020, Aalborg, Denmark. pp.264 - 273, 10.5771/9783956507762-264 • hal-03195760

\author{
HAL Id: hal-03195760 \\ https://hal.science/hal-03195760
}

Submitted on 13 Apr 2021

HAL is a multi-disciplinary open access archive for the deposit and dissemination of scientific research documents, whether they are published or not. The documents may come from teaching and research institutions in France or abroad, or from public or private research centers.
L'archive ouverte pluridisciplinaire HAL, est destinée au dépôt et à la diffusion de documents scientifiques de niveau recherche, publiés ou non, émanant des établissements d'enseignement et de recherche français ou étrangers, des laboratoires publics ou privés. 
Daniel Martínez-Ávila - Universidad Carlos III de Madrid (UC3M), Spain Fidelia Ibekwe - Aix Marseille Univ, CNRS, LPL, Aix-en-Provence, France Fernanda Bochi - São Paulo State University (UNESP), Brazil

\title{
The Epistemic Communities and Evolution of Knowledge Domains
}

\author{
A Domain Analysis of the Journal Education for Information
}

\begin{abstract}
:
Bibliometrics has been presented as one of the approaches to domain analysis. In this context, the relationship between domain analysis and journals has also been explored. There have been several bibliometric studies of specific journals using a domain-analytic approach, often published in ISKO venues, such as those carried out on the journal Knowledge Organization, and the Spanish KO-specific journal Scire. These domain analyses helped to determine the relevance and interest of these journals for the $\mathrm{KO}$ and other communities. We propose to study the epistemic communities around the journal Education of Information. An Interdisciplinary Journal of Information Studies. One of the assumptions of our research is that the domain of a given journal is delineated by its epistemic communities. We performed simple bibliometric counts on authors' affiliations and number of co-authorships in order to identify research elites across the seven periods covering the existence of the journal (1983-2018). We then mapped the co-authorship networks of the journal in order to visualise how its epistemic communities emerged and changed during that time.
\end{abstract}

\subsection{Introduction}

The field of knowledge organization is institutionalized, among other things, by professorships at universities around the world, by teaching and research programs at institutions of higher education, by conferences such as the ISKO meetings and scholarly journals (Hjørland 2016). Scholarly journals are of utmost importance not only for the publication and socialisation of research but also for the shaping of the epistemic communities that constitute the domain. Scholars very often do not just consider themselves theoretically and socially integrated into a department or school of a higher institution, but feel more part of the community of researchers that publish, review, and interact in one or several journals that share paradigms and theoretical assumptions underlying their research domains. In this sense, we might say that the authors and the editorial committee of a journal contribute in defining the journal's domain in perhaps a more influential way than the journal's scope. Smiraglia $(2015,9)$ explained the relationship between journals and domains as follows:

"Journals are the formal venues for most scholarly communication, and studying them as whole works is also one means of identifying productive elements of a research front. Of course, few journals are devoted to topical areas that are as narrowly defined as most domains under study. For exampe [sic], even in the field of knowledge organization, the principle journal Knowledge Organization is devoted to the entire field. Thus, it would likely be the most cited journal in all domains within $\mathrm{KO}$, but there are no journals devoted to specific narrow aspects of $\mathrm{KO}$, such as "integrative levels," "multilingual thesauri," or "ethics in KO."”

Of course, this composition is complex and presents almost as many variables related to the definition of the domain as bibliometric indicators can be used for domain analysis.

Bibliometrics was presented by Hjørland $(2002 ; 2017)$ as one of the approaches to domain analysis. Several authors, including Chen, Ibekwe-SanJuan, and Hou (2010), 
Ibekwe-SanJuan (2008), Ibekwe-SanJuan and SanJuan (2010), and Smiraglia (2015), have explored, in practice, how bibliometrics can be used to map knowledge domains. In particular, Smiraglia has conducted some of the most prominent domain analyses for knowledge organization such as the bookshelf studies of the ISKO international proceedings (Smiraglia 2008; 2011; 2013; 2014; 2017; 2018). Other bibliometric studies have focused on the journal Knowledge Organization (Smiraglia 2012; Guimarães, Martínez-Ávila, and Alves 2015; Alves, Dalessandro, and Bochi 2019) and on the journal Scire (Guimarães, Pinho, and Ferreira 2012; Oliveira et al. 2017). Studies of other journals that also use bibliometric techniques especially in relation to authorship and that could also be considered domain analyses in this vein include those carried out on the journal Scientometrics (Oliveira and Grácio 2012) and Journal of Informetrics (Hilário and Grácio 2018).

Our study aims to identify the epistemic communities formed around the journal "Education of Information. An Interdsiciplinary Journal of Information Studies" (EFI) using simple bibliometric techniques that focus on bibliographic units such as authors' affiliations, co-authorships and research elites. A core assumption of our research is that the domain of a given journal can be delineated by the epistemic communities identified with it. This is especially important for journals that are not highly specialised and have a general scope that might correspond to broad categories such as JCR's "Information Science \& Library Science" or Scopus's "Library and Information Sciences"; or for journals whose titles suggest an interdisciplinary scope. For instance, the journal under study was called "Education for Information" (EFI) until early 2019 when the subtitle "An Interdsiciplinary Journal of Information Studies" was added to it. The word "education" in its title continues to attract submissions from scholars in the field of education despite its aspiration to be an interdisciplinary journal in the broad field of LIS journal as shown by its scope ${ }^{1}$. This journal welcomes papers on knowledge organization as part of the LIS field and has a good number of ISKO researchers in its editorial board.

\subsection{Method}

The journal Education for Information was founded in 1983. To perform an analysis of the most productive affiliations, authors, and co-authorship networks, we split its 36 years of existence into seven five-year periods. According to Guimarães, MartínezÁvila, and Alves (2015), "a five-year period is considered to be an adequate range to characterise scientific production." Indeed, this was the time range used by these authors to study the epistemic communities of the journal Knowledge Organization. We also believe five-year periods is an adequate range to study the evolution of the 36 years of existence of the journal in seven periods as this number of periods presents a good balance between manageability and a good level of detail for the analysis. Using Price's Elitism Law (Price 1963) that indicates that the elite of a certain domain (the most productive authors) is represented by the square root of the total amount of authors or publications of the studied domain, we calculated the research elites and the most productive institutions using authors' affiliations as input.

${ }^{1}$ See https://www.iospress.nl/journal/education-for-information/ for its scope. 
Price's Elitism Law has been used in bibliometric studies applied to knowledge organization (Guimarães and Tennis 2012). For the co-authorship networks, we used the software Ucinet version 6.6 and built seven matrices of authors for the seven periods $(20 \times 20,28 \times 28,57 \times 57,53 \times 53,21 \times 21 ; 49 \times 49 ; 49 \times 49)$. We standardised the name of these authors using the authority records of Scopus and the Web of Science when available, in order to avoid redundancies and variations in the names of the same authors.

\subsection{Results}

The authors in the research elites come from a total of 53 institutions based on their afilliations. Figure 1 shows the nine most productive institutions across the seven 5 year periods. The results show the leading role of the Aberystwyth University, and more specifically the College of Librarianship Wales (CLW) with $29.09 \%$ (16) of EFI publications in the first ten years (1983-1992). According to its biographical history ${ }^{2}$, the CLW was established in 1964 and it was the first library school in Wales. In 1989, the college merged with the University of Wales, Aberystwyth, becoming the Department of Information and Library Studies. The second institution by order of publications in EFI is McGill University in Canada with $16.37 \%$ (9) of the publications distributed in three periods (1983-1987, 1993-1997, 2013-2018). The publications come from three different units at McGill University: the School of Information Studies, the McLennan-Redpath Library, and the Department of Family Medicine. The University of Northumbria at Newcastle in the United Kingdom, the University of Ibadan in Nigeria, Robert Gordon University in the United Kingdom, and Charles Sturt University in Australia, each represented 9.09\% (5) of the publications in the seven periods. The contributions of these four institutions come from departments in Library and Information Science. The University of Sheffield in the United Kingdom was present in the first three periods with 7.28\% (4) publications while Queen's University of Belfast and Loughborough University in the United Kindom each accounted for $5.45 \%$ (3) of the publications.

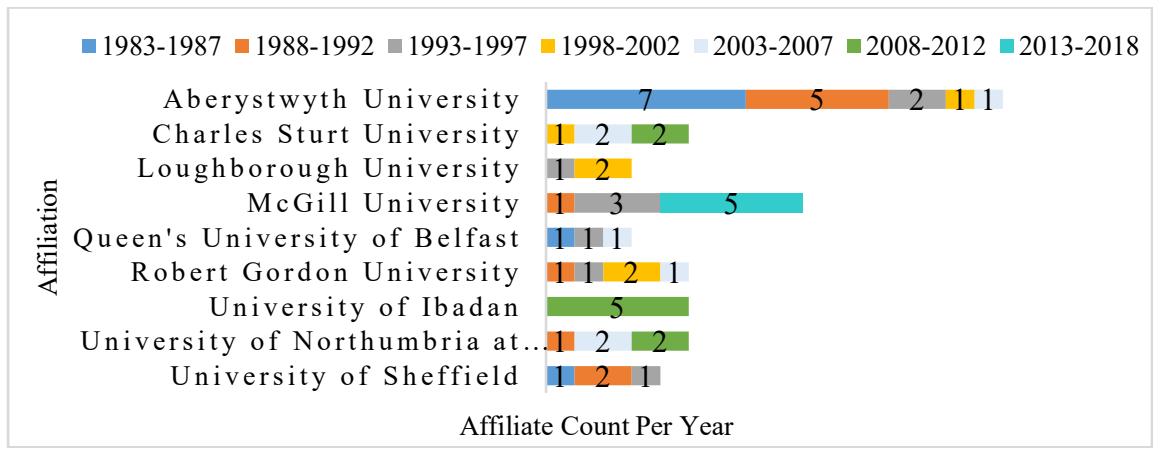

Figure 1. Most representative affiliations of the contributions to the journal Education for Information

\footnotetext{
${ }^{2}$ College of Librarianship Wales Archive. Available at:

https://archiveshub.jisc.ac.uk/search/archives/cdacfffe-c278-3ac6-aee6-76cf7d465886
} 
Table 1 below shows that in the first three five-year periods (1983-1997), John Andrew Large (henceforth Large JA), who was the first Editor in Chief (EIC) of the journal from 1983 to 2013, was also its most productive author. This points to the prominent role played by the EIC in establishing the journal, expanding and consolidating its authorship networks and thus its initial epistemic community. This assumption is supported by the co-authorship networks we uncovered for the seven five-years periods of the study (see Figure 2 hereafter).

Table 1. Research elite of the journal Education for Information for the períod 1983-2018

\begin{tabular}{|c|c|c|c|}
\hline Years & Authors & Articles Published & Country \\
\hline \multirow[t]{17}{*}{ 1983-1987 } & Christine J. Armstrong & 7 & United Kingdom \\
\hline & Blaise Cronin & 5 & United Kingdom \\
\hline & John Andrew Large & 5 & United Kingdom \\
\hline & Harold Borko & 4 & United States \\
\hline & Norman Roberts & 4 & United Kingdom \\
\hline & Derryan Paul & 4 & United Kingdom \\
\hline & Gayle Edward Evans & 4 & United States \\
\hline & Kevin J. McGarry & 4 & United Kingdom \\
\hline & Richard J. Hartley & 3 & United Kingdom \\
\hline & Noragh Jones & 3 & United Kingdom \\
\hline & Marianne Broadbent & 3 & Australia \\
\hline & M. Wise & 3 & United Kingdom \\
\hline & John Harris & 3 & United Kingdom \\
\hline & Michael E.D. Koenig & 3 & United States \\
\hline & John R. Turner & 3 & United Kingdom \\
\hline & William Fisher & 3 & United States \\
\hline & William J. Martin & 3 & United Kingdom \\
\hline \multirow[t]{15}{*}{ 1988-1992 } & John Andrew Large & 13 & United Kingdom \\
\hline & Norman Roberts & 5 & United Kingdom \\
\hline & Ian M. Johnson & 5 & United Kingdom \\
\hline & Alan J. Clark & 5 & United Kingdom \\
\hline & Richard J. Hartley & 4 & United Kingdom \\
\hline & Joan M. Day & 4 & United Kingdom \\
\hline & Blaise Cronin & 4 & United Kingdom \\
\hline & Yves Courrier & 4 & France \\
\hline & Thomas D. Wilson & 3 & United Kingdom \\
\hline & Ronald J. Edwards & 3 & United Kingdom \\
\hline & Kevin J. McGarry & 3 & United Kingdom \\
\hline & David P. Woodworth & 3 & United Kingdom \\
\hline & Mary Nassimbeni & 3 & South Africa \\
\hline & Helen Howard & 3 & Canada \\
\hline & Robin Frederick Guy & 3 & United Kingdom \\
\hline \multirow[t]{12}{*}{ 1993-1997 } & John Andrew Large & 8 & Canada \\
\hline & Thomas A Schröder & 8 & Germany \\
\hline & Robin Frederick Guy & 7 & United Kingdom \\
\hline & Thomas D. Wilson & 5 & United Kingdom \\
\hline & France Bouthillier & 3 & Canada \\
\hline & Alan J. Clark & 3 & United Kingdom \\
\hline & Anne Goulding & 3 & United Kingdom \\
\hline & Marcos Silva & 3 & Canada \\
\hline & Clive Cochrane & 3 & United Kingdom \\
\hline & Peter G. Underwood & 3 & United Kingdom \\
\hline & Douglas Anderson & 3 & United Kingdom \\
\hline & Flora Smith & 3 & United Kingdom \\
\hline \multirow[t]{2}{*}{ 1998-2002 } & Ian M. Johnson & 6 & United Kingdom \\
\hline & Anne Goulding & 4 & United Kingdom \\
\hline
\end{tabular}




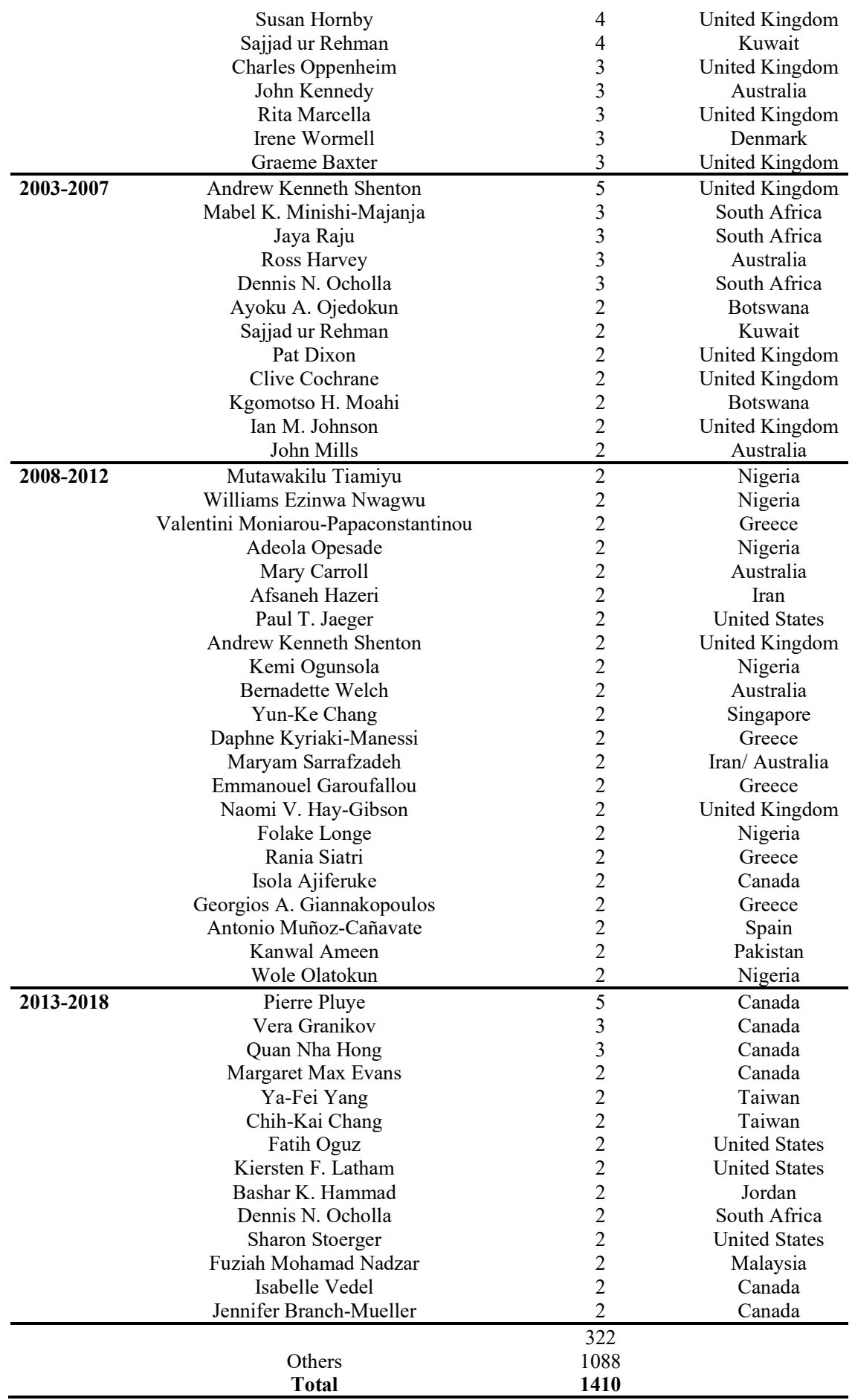


In Figure 2, red squares represent the authors from the research elites of the journal, blue squares represent the co-authors of the research elite, while the thickness of the lines (edges) represent the intensity of the co-authorships as shown by number of times they co-authored a paper. Scientific collaboration, as a social activity of science, originates from the relations between two or more authors, promoting their visibility, confronting the similarities and differences of their knowledge, and contributing to the emergence of new concepts and domains (Hilário \& Grácio, 2011).

In the first period (1983-1987), the network was very sparse and there were few coauthorships, most were made up of no more than two authors and a few isolated nodes (lone authorships). The publications were concentrated among the research elite of the time, notably Large JA, then editor in chief of the journal, and Armstrong CJ who worked at the same institution as Large JA were co-authors in one subgraph. In this first period, the epistemic community of the journal was emerging and not yet structured.

In the second period (1988 to 1992), a more interconnected network became visible with four subgraphs, each of which has three or more nodes of coauthorships and a few lone authors. Although many of the research elite were still in single authorship, multiple collaborations in triads appeared, such as the one between "Edwards RJ, Wilson TD, Roberts N, and Cronin B". In this period, Large JA co-authored a paper with four authors forming a pentagonal network. This indicates increased collaborations between authors and a structuring of the epistemic communities around the journal.

Price (1963) believed that due to the exponential growth of the number of publications in co-authorship, single authorship would cease to exist. Although single authorship was a significant practice during the first ten years of existence of the journal, we observe that especially after 1993 this practice decreases in favour of co-authorships.

In the third period (1993-1997), the network became even more dense. A huge interconnected subgraph shows Large JA (30) at its center, followed by Smith F (16), Anderson D (13), Underwood PG (12) (see Table 2). These authors were also part of the research elite of this period. Two other people who also held editorship roles in the journal were very centrally placed in the network: Hartley RJ (6) was book reviewer for the journal between 2000-2001 and subsequently joint-editor-in-chief; Guy RF (4) was editor-in-chief together with Large JA at the start of the journal. Two other smaller but dense networks in this period show authors like Wilson TD and Goulding A as central nodes, all of them being part of the research elite. 


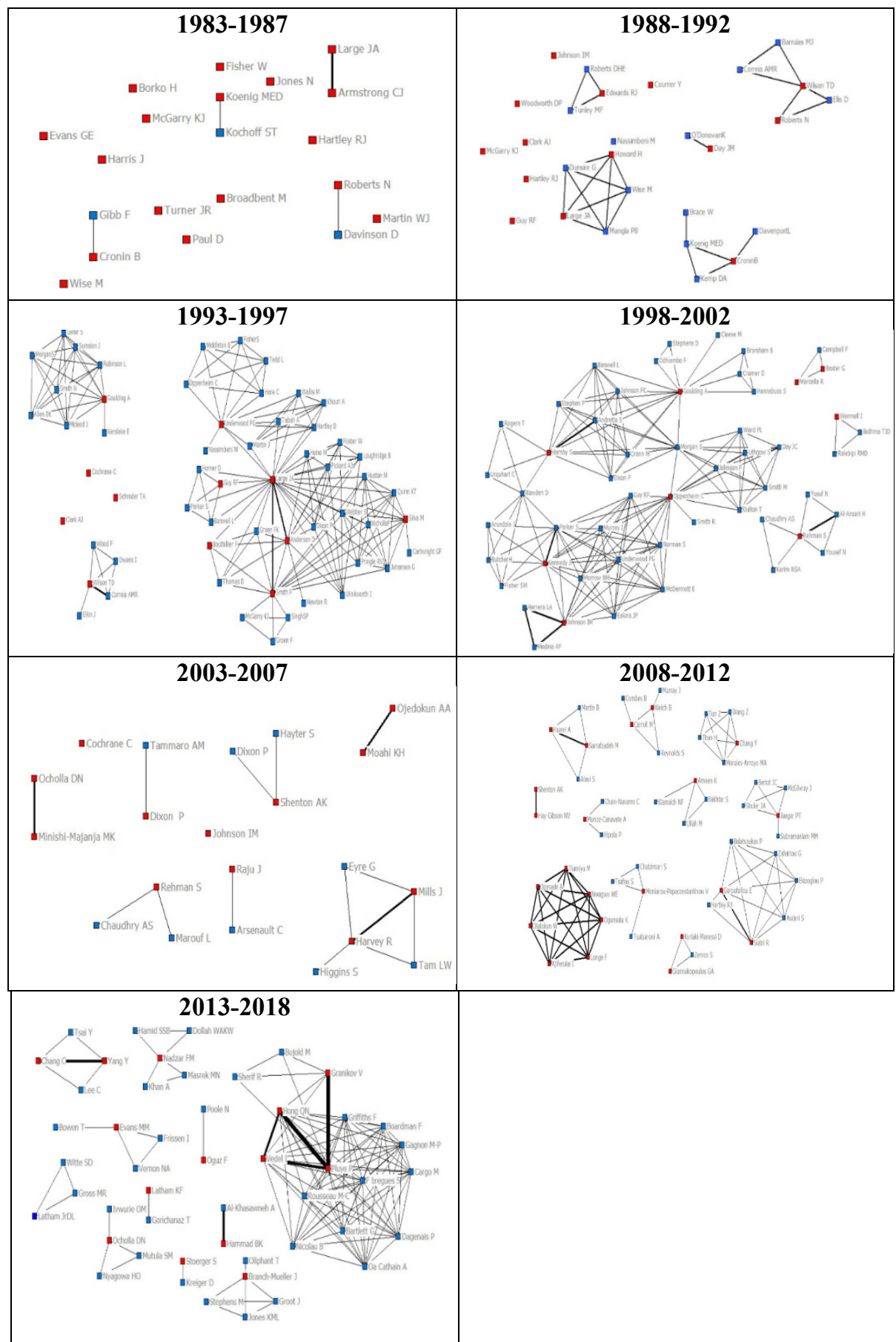

Figure 2: The seven co-authorship networks of Education for Information for the period 1983-2018. 
It appears then that in its first three periods of the journal's existence (1983-1997), the editor-in-chief (Large JA) played a major role in structuring the co-authorship networks and in shaping its epistemic communities.

Bourdieu (1983) stated that scientific capital can be accumulated or even transferred and that it is directly related to the scientific prestige and trajectory of the researcher. This idea reinforces our assumption about the key role of a journal's editor-in-chief in the emergence, growth and development of a scientific journal.

After 1998, Large JA no longer appeared as part of this journal's research elite, suggesting that while the journal needed the scientific capital of its founding editor-inchief to give it prestige during its formative years, once this has been achieved, the journal began to build on this and to consolidate its own scientific capital. This assumption seems to be borne out by the subsequent co-authorship networks after the first three periods (1998-2018). While the journal's original research elites were predominantly from the United Kingdom (like its first editor-in-chief) and the United States, research elites emerged from other parts of the world (South Africa, Nigeria, Kuwait, Australia, Greece, and Canada).

In the fourth period (1998-2002), the networks continued to display a greater degree of connectivity with most authors being either directly or indirectly connected with the others, with the exception of three small subgroups. The authors with the most coauthorships were Oppenheim C (18) who is placed at the transition point between two interconnected networks. Kennedy J (15), Parker S (15), Hornby S (12) and Morgan S (15) appeared as hubs in the networks.

By contrast with the two preceding periods, the network of co-authorships became very sparse in the fifth period (2003-2007) with a few disparate subgraphs, each with two or three nodes and each disconnected from the others. The journal's editors who had been present in the preceding periods, and thus instrumental in structuring its epistemic communities were noticeably absent in the network for this period. One wonders why the epistemic communities which had been coalescing around the journal over the first twenty years appear to have disintegrated. This period seems to be a sort of "turning point" (point de rupture) for the journal and may be a sign of disengagement in the journal by its founding editors-in-chief and his network. A more qualitative analysis is required to understand what happened at this time in the journal's life.

In the sixth period (2008-2012), a new epistemic community seems to emerge comprising two densely connected and moderately sized subgraphs. One completely interconnected subgraph was built around the following authors: Olatokun W, Opesade A, Longe F, Nwagwu WE, Ajiferuke I, Ogunsola K, and Tiamiyu M). Apart from Ajeferiku who is based in Canada, his co-authors are all based in the Africa Regional Centre for Information Science, University of Ibadan, in Nigeria. The rest of the network showed very disconnected subgroups in which the majority of the clusters correspond to the publications that the members of the subgroups shared. Thus, we observe a shifting of th journal's center of gravity outside the UK and North America.

In the last seventh period (2013-2018), a very dense network appears around Pluye P (20), a professor at the University of McGill (Canada). This dense subgraph is explained by the fact that Pluye P. co-guest edited a series of special issues of the journal on Health information evaluation with a fellow team member Granikov V. Hence, the densely connected subgraph is a direct result of the tradition of multiple co- 
authorships within this team from the Department of Family Medicine and the School of Information Studies at McGill University. The other smaller subgroups show fewer number of nodes. The biggest collaborations here have no more than four nodes, as in the case of the membersof the research elite Nadzar FM and Branch-Mueller J.

\subsection{Conclusion}

Grácio (2018) pointed out that scientific collaboration manifests itself through the collective intellectual work, promoting an association of skills and knowledge, uniting researchers with thematic proximity, and sometimes approximating researchers from different areas. Our study showed the crucial role played by a scientific journal's editor-in-chief in the emergence, development, and consolition of its epistemic communities which in turn structures research fields. In the case of the journal Education for Information, its first editors-in-chief (Large JA, Hartley RJ) occupied prominent and central positions in the first three periods of the existence of the journal when it needed to gain visibility and credibility as a channel for scholarly publication in the interdisciplinary field of LIS. Once the epistemic communities were consolidated, the influence of its founding editors-in-chief waned and eventually disappeared as they either shifted their attentions elsewhere or left their editorship positions. With the change of editorship in 2014, new more diverse and international epistemic communities began to coalesce around the journal. This indicates that while the journal benefitted from the scientific capital of its founding editors in its first two decades of existence, a point of rupture (split) occurred afterwards in which the epistemic communities built by the founding editors were phased out. As the journal consolidated its reputation, it attracted authors from outside this historic epistemic community, thus arriving at a more diverse and international epistemic communities that are clearly different from those of the founding editors.

\section{References}

Alves, Bruno Henrique, Rafael Cacciolari Dalessandro, and Fernanda Bochi dos Santos. 2019. "Colaboração Científica no Periódico Knowledge Organization: Elementos para Caracterização de um Domínio" In: Organização do Conhecimento Responsável: Promovendo Sociedades Democráticas e Inclusivas, edited by Thiago Henrique Bragato Barros and Natalia Bolfarini Tognoli. Belem: Ed. da UFPA, 137-144.

Bourdieu, Pierre. 1983. "O Campo Científico." In Pierre Bourdieu: Sociologia, edited by Renato Ortiz. São Paulo: Ática, 122-155.

Chen, Chaomei, Fidelia Ibekwe-SanJuan, and Jianhua Hou. 2010. "The Structure and Dynamics of Co-Citation Clusters: A Multiple-Perspective Co-Citation Analysis." Journal of the American Society for Information Science \& Technology 61, no. 7: 1386-1409.

Grácio, Maria Cláudia Cabrini. 2018. "Colaboração Científica: Indicadores Relacionais de Coautoria." Brazilian Journal of Information Science 12, no. 2: 24-32

Guimarães, José Augusto, Fabio A. Pinho, and Gustavo M. Ferreira. 2012. "Relações Teóricas da Organização do Conhecimento com as Abordagens de Catalogação de Assunto, Indexação e Análise Documental." Scire 18, no. 2: 31-41.

Guimarães, José Augusto Chaves, Daniel Martínez-Ávila, and Bruno Henrique Alves. 2015. "Epistemic Communities in Knowledge Organization: An Analysis of Research Trends in the Knowledge Organization Journal." Paper resented at ISKO UK biennial conference 13th - 14th July 2015, London. 
http://www.iskouk.org/content/epistemic-communities-knowledge-organization-analysisresearch-trends-knowledge-organization

Guimarães, José Augusto Chaves and Joseph T. Tennis. 2012 "Constant Pioneers: The Citation Frontiers of Indexing Theory in the ISKO International Proceedings." In Categories, Contexts and Relations in Knowledge Organization: Proceedings of the Twelfth International ISKO Conference 6-9 August 2012, Mysore, India, edited by A. Neelameghan and K. S. Raghavan. Advances in knowledge organization 13. Würzburg: Ergon Verlag, 39-43.

Hilário, Carla Mara and Maria Cláudia Cabrini Grácio. 2011. "Colaboração Científica na Temática "Redes Sociais": Uma Análise Bibliométrica do ENANCIB no Período 2009-2010." Revista EDICIC 1: 363-375.

Ibekwe-SanJuan, Fidelia. 2008. "The Impact of Geographic Location on the Development of a Specialty Field: A Case Study on Sloan Digital Sky Survey in Astronomy." Knowledge Organization 35: 239-250.

Ibekwe-SanJuan Fidelia and Eric SanJuan. 2010. "Knowledge Organization Research in the Last Two Decades: 1988-2008." In Paradigms and Conceptual Systems in Knowledge Organization: Proceedings of the Eleventh International ISKO Conference 23-26 February 2010, Rome, Italy, edited by Claudio Gnoli and Fulvio Mazzocchi. Advances in knowledge organization 12. Würzburg: Ergon Verlag, 115-121.

Hilário, Carla Mara and Maria Cláudia Cabrini Grácio. 2018. "Análise de Citações Considerando a Contribuição dos Autores e Ordem da Autoria nos Artigos do Journal of Informetrics." In: XIX Encontro Nacional de Pesquisa em Ciência da Informação - ENANCIB 2018, 4327 4342

Hjørland, Birger. 2002. "Domain Analysis in Information Science: Eleven ApproachesTraditional as well as Innovative." Journal of Documentation 58: 422-62.

Hjørland, Birger. 2016. "Knowledge Organization (KO)." Knowledge Organization 43: 475484.

Hjørland, Birger. 2017. "Domain Analysis.” Knowledge Organization 44: 436-464.

Oliveira, Ely Francina Tannuri de, Bruno Henrique Alves, Marcos Rodrigues do Prado, and Maria Aparecida Pavanelli. 2017. "Produção Científica e Inserção Internacional da Revista Scire no Período de 2006 a 2014." Scire 23, no. 1: 47-56.

Oliveira, Ely Francina Tannuri de and Maria Cláudia Cabrini Grácio. 2012. "Visibilidade dos Pesquisadores no Periódico Scientometrics a Partir da Perspectiva Brasileira: Um Estudo De Cocitação." Em Questão 18, no. 3: 99-113.

Price, Derek J. de Solla. 1963. Little Science, Big Science. New York, Columbia.

Smiraglia, Richard P. 2008. "ISKO 10's Bookshelf. An Editorial." Knowledge Organization 35: 187-191.

Smiraglia, Richard P. 2011. "ISKO 11's Diverse Bookshelf: An Editorial.” Knowledge Organization 38: 179-186.

Smiraglia, Richard P. 2012. "Shifting Intension in Knowledge Organization: An Editorial." Knowledge Organization 39: 405-408.

Smiraglia, Richard P. 2013. "ISKO 12's Bookshelf- Evolving Intension: An Editorial." Knowledge Organization 40: 3-10.

Smiraglia, Richard P. 2014. "ISKO 13's Bookshelf: Knowledge Organization, the Science, Thrives-An Editorial." Knowledge Organization 41: 343-356.

Smiraglia, Richard P. 2015. Domain Analysis for Knowledge Organization: Tools for Ontology Extraction. Oxford: Chandos Publishing.

Smiraglia, Richard P. 2017. "ISKO 14's Bookshelf: Discourse and Nomenclature-An Editorial." Knowledge Organization 44: 3-12.

Smiraglia, Richard P. 2018. "ISKO 15's Bookshelf: Dispersion in a Digital Age. An Editorial." Knowledge Organization 45: 343-357. 